\title{
Crustal Structure and Seismogenic Zone of Cameroon: Integrated Seismic, Geological and Geophysical Data
}

\author{
Eloumala Onana Parfait Noel'1, Mouzong Pemi Marcelin² ${ }^{2}$ Ateba Bekoa ${ }^{3}$ \\ ${ }^{1}$ Civil Engineering Department, University Institute of Technology (IUT), Douala, Cameroon \\ ${ }^{2}$ Physics Department, Sciences Faculty, University of Yaoundé, Yaoundé, Cameroon \\ ${ }^{3}$ Antenna of Geophysics and Volcanology Researches (ARGV), Buea, Cameroon \\ Email: parfaitnoele@yahoo.fr
}

Received 18 September 2014; revised 20 October 2014; accepted 17 November 2014

Copyright (C) 2014 by authors and Scientific Research Publishing Inc.

This work is licensed under the Creative Commons Attribution International License (CC BY).

http://creativecommons.org/licenses/by/4.0/

(c) (i) Open Access

\section{Abstract}

This study describes the seismo-tectonic evolution of Cameroon. It is noticed that seismic activity is largely related to the Cameroon volcanic line (CVL) and many of the tectonic phenomena follow the previous structural lines. Although the area is that of a relatively low seismicity, the effects of a given earthquake could be considerable. This study combines seismic records, from 1952 to 2002 and from 2005 to 2007, with the integration of existing structural information to better define the seismogenic zones. An important identified cluster of epicenters in $S-W$ defines the first seismic source region where events' characteristics show a weak seismicity related to volcanic activity. The second seismogenic zone, in the north of Mount Cameroon volcano, illustrates the activity of Central Cameroon Shear Zone (CCSZ) faults; its seismicity is considered weak to moderate with maximum magnitude recorded which is $5.1 \mathrm{Mb}$. The area of "Sanaga Shear Zone" (SSZ) constitutes the third seismic source region with moderate seismicity in which maximum magnitude recorded is $5.8 \mathrm{Mb}$; Depth of its faults segments is evaluated at $33 \mathrm{~km}$. The fourth Source Region follows the North boundary of Congo Craton; a characteristic event with magnitude of 6 M allows evaluating fault depth at $33 \mathrm{~km}$. Also three zones define crustal structure: the South Domain with thick crust, the Center Domain characterized by thin crust, active tectonic and volcanic structures and the north domain with shallow Moho.

\section{Keywords}

Seismogenic Zones, Source, Shear Zone, Crustal Structure 


\section{Introduction}

Cameroon spans the area between latitude $2^{\circ} \mathrm{N}$ to $13^{\circ} \mathrm{N}$ and longitude $08^{\circ} \mathrm{E}$ to $16^{\circ} \mathrm{E}$. It corresponds to a complex which includes the Congo Craton in the South and the major geological feature in Central Africa called "Cameroon Volcanic Line”, uprising from the West in the Gulf of Guinea to the North (Figure 1).

The edification of Cameroon has developed grabens, horsts, and tectonic lineaments which are superimposed on older structures. Fault structures can be considered in three main groups according to the direction of lineaments: ENE-WSW, NNE-SSW and ESE-WNW (Figure 2). As a consequence, Cameroon is characterized by heterogeneous seismicity where earthquakes that affect most parts are located around the mount Cameroon. The 6.0 Ms earthquake on September 12, 1945 (IRGM, 2002) that hit the south region is one of the largest earthquakes in the country in the historical era of earthquake feeling.

The Moho (Mohorovičić discontinuity) that separates the Earth's crust from the underlying mantle is characterized by major changes in seismic velocity, chemical composition, and rheology [1]. Depth to Moho also varies according to the geo-tectonic evolution of each area.

Although the structures have been the subject of several previous papers, till date, little has been done to identify the seismogenic zone and to confirm the vulnerability of the study area. This study characterizes the recent seismicity of the Cameroon and examines the influence of the structure on the overall seismicity of the region. It also provides information about earthquakes prone areas, seismic zoning maps and crustal thickness for Cameroon. The correlation of seismic, geological and geophysical data allows for a better seismo-tectonic analysis and understanding of the implications for seismic hazard. This work shows three main parts of analysis including the crustal structure, the spatial distribution of events and the "Seismic Source Regions". It identifies structures generating events, characterizes density of seismicity and allows the establishment of the relationship between seismicity and tectonic structures.

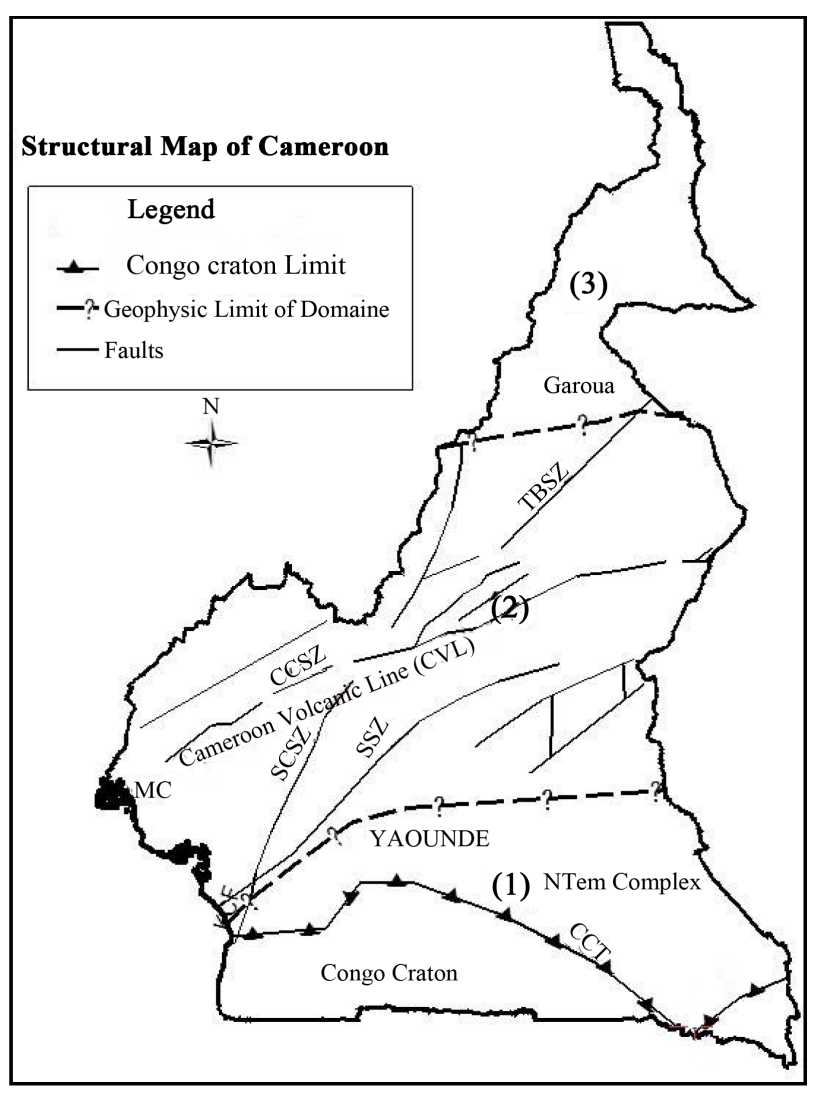

Figure 1. Structural map of Cameroon. CCSZ: Cameroon Shear Zone; SSZ: Sanaga Shear Zone; SCSZ: South Cameroon Shear Zone; CCL: Congo Craton Limit; TBSZ: Tcholliré-Banyo Shear Zone; KCF: Kribi-Campo Fault; MC: Mont Cameroon. 


\section{Geodynamic Setting}

Cameroon has known three orogenic cycles:

1) The Liberian cycle is illustrated by the Ntem complex in South Cameroon. It dates from the Archaean era (about 2.5 billion years old) and is bounded by major thrusts that separate it from the Nyong unit in the North West and the Pan-African Yaoundé Group in the North [2].

2) The Eburnean or Transamazonian cycle dates from the Palaeoproterozoic period (2.5 - 1.8 billion years ago). It corresponds to the Nyong and Ayna formations, respectively in the West border of Congo Craton and in the East of Ntem complex.

3) The Pan-African cycle, which comprises formations from the Neoproterozoic era 1000 - 600 million years (Ma) ago, includes three main groups (Figure 1) [3] [4]: the southern Domain a) consists of the Yaoundé Group which is limited to the west by the Kribi-Campo fault; The central domain b) (Adamaoua-Yaoundé area) lies from the north of the Sanaga fault to Tcholliré Banyo shear zone; The northern domain c) which is located north of the Tcholliré-Banyo shear zone and extends along the western edge of Cameroon. It continues in the regions of Poli.

\section{Geology Setting}

The geological history of Cameroon begins with the Archaean era between 3.5 and 2.5 billion years (Ga) ago. Its different phases of development are illustrated by geological masses formed during successive orogenic cycles. It is characterized by formation of craton and mountain ranges, and subsequent extension phases by the splitting of the continental crust. From the South to the North we have (Figure 1):

1) The Cameroonian southern domain consists of Pan-African meta-sedimentary units such as the Ntui-Betamba, Yaoundé and Ayos-Mbalmayo-Benbis units. The layers were plunged onto the Archaean Congo Craton towards the South [3] from this domain, which were affected by four stages of ductile deformation, corresponding to alternating phases of E-W to NW-SE contraction (D1, D3) and N-S to NE-SW extension D2 [5].

2) The Cameroonian central domain, broad area that extends between the fault of the Sanaga to the South and the Tibati-Banyo fault to the North. It consists of Archaean to Palaeoproterozoic high-grade gneisses intruded by widespread Pan-African syntectonic plutonic rocks of high-K calc-alkaline affinities [6]. Major setbacks in this area seem to have guided the implementation of plutonism having an orthogneissification with variable intensity. This area is subjected to an advanced general metamorphism where banking is composed of gneiss and amphibolite.

3) The Cameroonian northern domain is characterized by subordinate 830 Ma old meta-volcanic rocks of tholeiitic and alkaline affinities associated with meta-sediments known as the Poli series. This domain is characterized by three stages of deformation: an early phase D1 is associated to the metamorphism with granulite facies, medium pressure [7]. A phase D2 dated 600 - $580 \mathrm{Ma}$ is synchronous with an intense migmatization [7] and a granitization associated to a metamorphism with amphibolite facies $\left(600^{\circ} 5-7 \mathrm{~Kb}\right)$ and greenschistfacies $\left(550^{\circ} 5 \mathrm{~Kb}\right)$. And a phase D3 is liable to the dextral setbacks E-W and drive folds N-S to E-W.

\section{Major Tectonic Structures}

The region of Cameroon corresponds to a complex which includes the Congo Craton, major geological feature in Central Africa called "Cameroon Volcanic Line” and diverse tectonic structures (Figure 1). Its edification developed grabens, horsts, and tectonic lineaments which were superimposed on older structures. The fault systems which influence the geodynamic evolution can be considered in different main groups [4] [8]:

1) The ENE-WSW $\left(30^{\circ} \mathrm{N}-60^{\circ} \mathrm{N}\right)$ fault set, the most frequent of the structural trends, was developed at the end of the Cretaceous. It is made up of: Cameroon Shear Zone (CCSZ), Sanaga Shear Zone (SSZ) and Tcholliré Shear Zone (TBSZ).

Central Cameroon Shear Zone (CCSZ) is a fault zone in Cameroon which is part of Central Africa Shear zone. It extends from the Trans-Brazilian Lineament to Sudan. The zone was rejuvenated several times, usually with a dextral movement, before and during the opening of the South Atlantic in the Cretaceous period [9]. The CCSZ underlies a chain of extinct volcanoes, called “Cameroon Volcanic Line” which includes the active volcanos as Mount Cameroon, Nyos and Monoun crater lakes and non-active others.

Sanaga Shear Zone (SSZ), Precambrian Central African Shear Zone, had a prior dextrial movement probably during the end of the Pan-African orogeny, and a later N-S shortening. It is expected to be implicated 
in a dextrial movement of the northern part of the Mobile Zone [4].

TheTchollire-Banyo Shear Zone (TBSZ) is thePrecambrian Central African Shear Zone which extends across the African continent from the Darfur in Sudan, through Central Africa, to the Adamawa Plateau in Cameroon [10]. The Pernambuco lineament in Brazil is probably the extension of the shear zone on the conjugate Atlantic-rifted margin [9].

Geo-tectonic studies along the Central African Shear Zone estimate $\geq 40 \mathrm{~km}$ of dextral displacement [11].

2) The NNE-SSW $\left(00^{\circ} \mathrm{N}-15^{\circ} \mathrm{N}\right)$ lineament principally includes South Cameroun Shear Zone (SCSZ). Many segments are identified as the Kribi-Campo Fault (KCF) trends almost in a north-south direction and may correspond to the north-western margin of the Congo Craton.

3) The ESE-WNW $\left(095^{\circ} \mathrm{N}-110^{\circ} \mathrm{N}\right)$ lineament marks out the limit between the Congo Craton with Archaen rocks in the South and the mobile zone with reworked Paleoproterozoic material in the North. This lineament of faults called Congo Craton Limit (CCL) is located around the parallel of latitude $4^{\circ} \mathrm{N}$. Aeromagnetic studies have shown that the limit of the Congo Craton is characterized by a series of buried and deep seated fault [12]. The recent studies [13] show that the crust thickness in the Craton complex is around $43 \mathrm{~km}$ to $45.5 \mathrm{~km}$ and beyond.

The Cenozoic Cameroon Volcanic Line (CVL) trends $30^{\circ} \mathrm{N}$ and extends from Pagalu Island to northernmost Cameroon. The lithosphere-asthenosphere boundary is $<100 \mathrm{~km}$ deep beneath the CVL and the mantle is characterized by slow seismic wave speeds [14]. A continuous low-velocity zone ( $\delta \mathrm{VS}=-2 \%$ to $-3 \%$ ) underlies the entire CVL to a depth of at least $300 \mathrm{~km}$ and was attributed to a thermal anomaly of $\geq 280 \mathrm{~K}$ [15]. Bulk crustal $\mathrm{Vp} / \mathrm{Vs}$ ratios along the CVL are markedly low with $\sim 1.74$ [14].

\section{Seismicity Knowledge}

Studies of continent-scale surface wave show that mantle structure beneath Cameroon is seismically slow [16] [17]. Seismic anisotropy in Cameroon which has been studied by [18] through analysis of SKS splitting allows to identify four regions of distinct anisotropy: moderately strong NE-SW oriented fast polarization directions $(\delta t \approx$ 1.0 s) beneath two region: the Congo Craton in the south and the Garoua rift in the north; weak anisotropy ( $\delta \mathrm{t} \approx$ $0.3 \mathrm{~s}$ ) between the Congo Craton and the CVL; N-S oriented fast polarization directions within the CVL, with $\delta \mathrm{t} \approx$ $0.7 \mathrm{~s}$. Koch et al. [18] interpreted these observations as evidence for small-scale mantle convection beneath Cameroon.

Tadjou et al. [19] help to constrain the lithospheric subdivisions of the region. For example, thinned crust ( $\sim 25 \mathrm{~km}$ ) is imaged beneath the Garoua Rift (Figure 2), while the transition from the CVL to the Congo Craton is characterized by a transition from $\sim 36 \mathrm{~km}$ thick crust to $43-48 \mathrm{~km}$ thick crust [13] [20]. Average crustal shear wave velocity also increases from the CVL with $\sim 3.7 \mathrm{~km} \cdot \mathrm{s}^{-1}$ into the craton with $\sim 3.9 \mathrm{~km} \cdot \mathrm{s}^{-1}[13]$.

\section{Seismic Data}

For this study, the seismic data we used are extracted from a variety of sources including: the Cameroonian catalogue established by Mining and Geological Research Institute [21] which covers the period from 1852 to 2002, the catalogue established from seismic data recorded by the temporary seismic network installed from 2005 to 2007 (Figure 2) and some events have been taken from international catalog as IRIS and ISC. We have also used crustal structure fund by [13] [17].

\section{Analysis and Interpretation}

\subsection{Evaluation of Crustal Thickness}

Using joint inversion analysis, [13] presented a crustal thickness underneath 30 stations installed in Cameroon and [16] presented a crustal thickness and mantle velocities maps for the African continent map using analysis of group velocity dispersion. From these data, we execute the interpolation on ArcGIS to create an outer and inner ellipse in order to obtain the crust thickness map. Thus, three main groups are observed:

Along the Cameroon volcanic line (CVL), the interpolation map shows that the crust thickness, less than 37 $\mathrm{km}$ depth, is low compared to both sides (Figure 3). This thickness varies from $37 \mathrm{~km}$ to $45 \mathrm{~km}$ in the southern side of the Congo Craton and also grows in the Northern side of CVL. Although the CVL is structured and up, the average Moho shows the compression conditions where lithosphere is deformed by uprising accompanied 


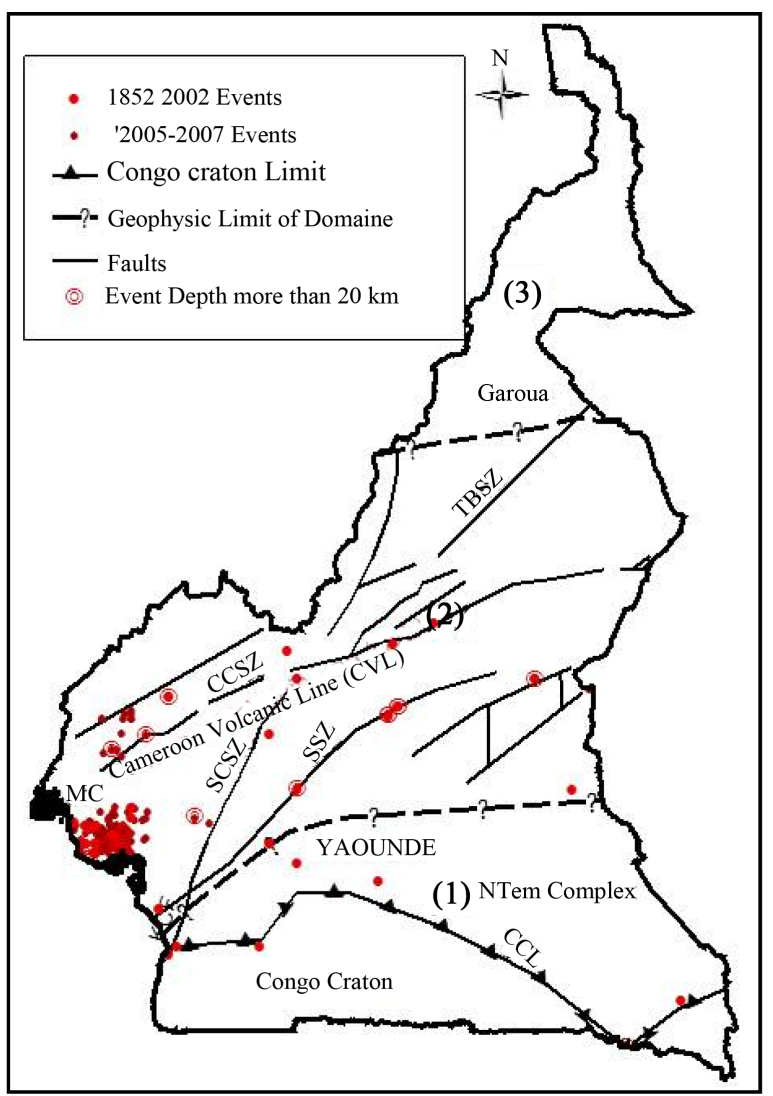

(a)

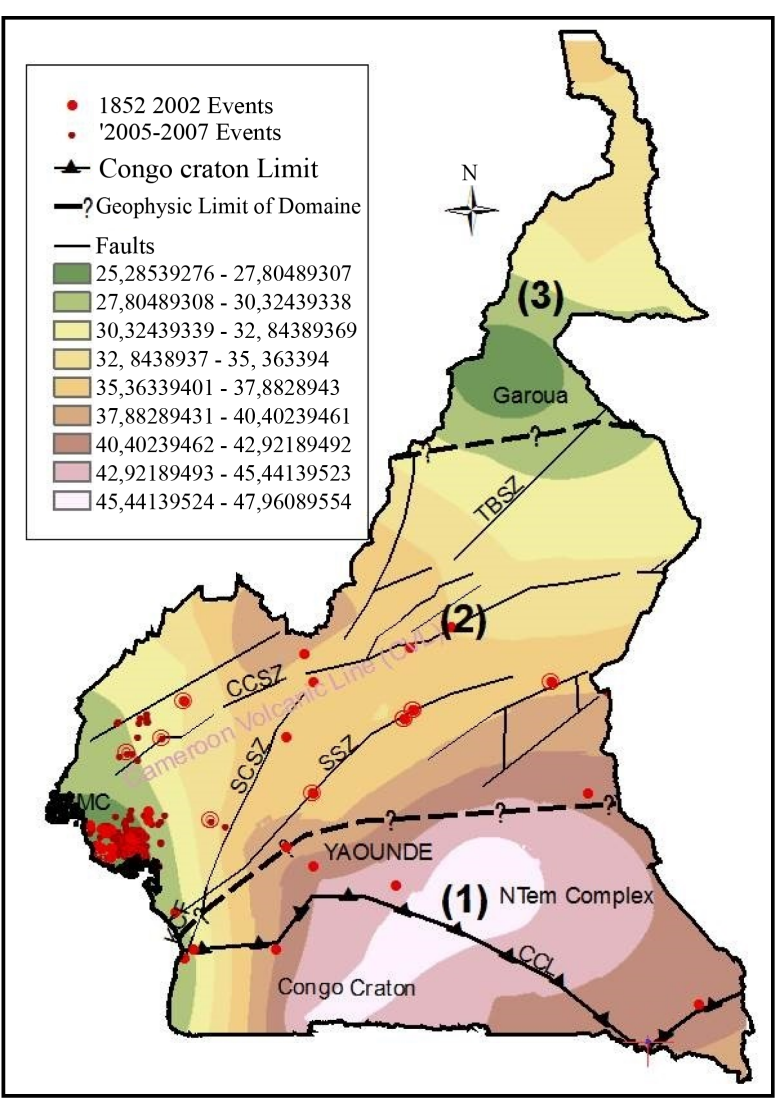

(b)

Figure 2. Seismicity map of Cameroun.

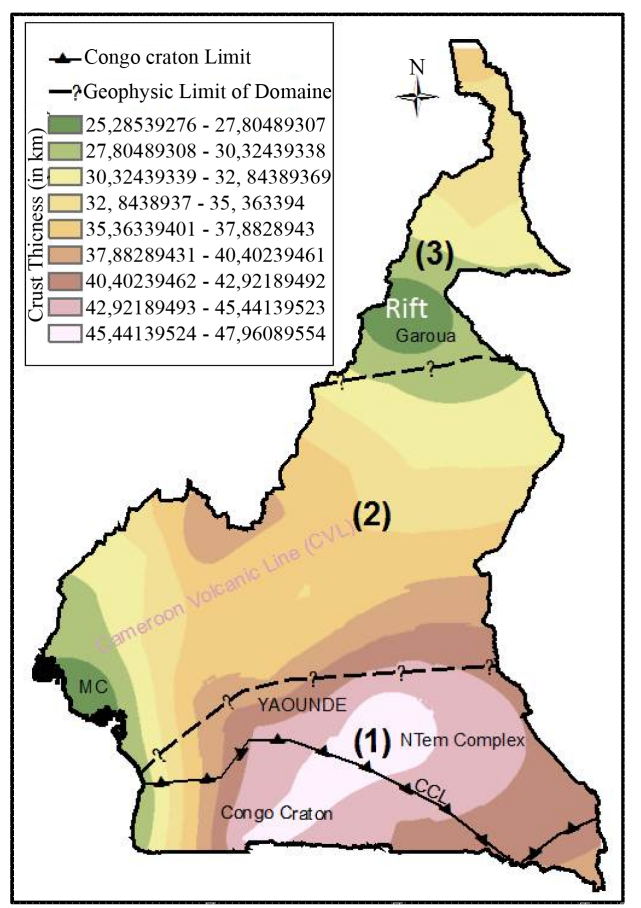

Figure 3. Crustal thickness map of Cameroon. MC: area of Mount Cameroon; CCL: Congo Craton Limit. The thickness varies from 25 to $47 \mathrm{~km}$. 
with thinning of the crust. The Moho and upper mantle are also uprising, there is no isostacy compensation root in such condition; rather the crust thickness decreases as a layer undergoing compressional stress.

Laterally of the Atlantic coastline, it appears that crustal thickness considerably decreases from inland to the Ocean. The sharp portion of Moho at about $25 \mathrm{~km}$ depth is observed in the area of Mount Cameroon. Thus, the Moho under this area, shallow and gradational, probably reflects a transitional zone between continental and oceanic crust. Shallow Moho is consistent with geologic and isostasy normal conditions, which suggest continental and oceanic Moho at 35 and $15 \mathrm{~km}$ respectively.

The Domain (3) is also characterized by shallow Moho where crust thickness decreases until $25 \mathrm{~km}$. This region corresponding to Garoua Rift that [18] has also identified through analysis of SKS splitting.

\subsection{Spatial Distribution of Seismicity and Tectonic Structures}

Cameroon has been the subject of several structural studies [13]-[15]. According to these studies, the available geotectonic data, combined with historical and recent seismic data, have allowed an improvement of the knowledge of the seismo-tectonics in the study area.

From the three main domains, the seismic activity is distributed mostly over the Central Domain, decreasing from the West to the East. A very dense concentration is observed in the Mount Cameroon region whereas very few events are located in the vicinity of strike-slip and thrust faults (Figure 3). The Southern Domain has also developed seismicity along the Northern boundary of Congo Craton.

Figure 4 shows the seismic events based on their focal depth. It can be seen that $28.6 \%$ of events occur at depths inferior to $1 \mathrm{~km}, 11.1 \%$ at depths between 1 and $5 \mathrm{~km}, 40.4 \%$ at depths between 5 and $10 \mathrm{~km}, 10.1 \%$ at depths between 10 and $20 \mathrm{~km}$ and $9.8 \%$ at depths between 20 and $40 \mathrm{~km}$. 79.5\% of the events are at very shallow depths inferior to $10 \mathrm{~km}$. Importantly, events occurring on the Sanaga Shear Zone (Seismic Source Region 3) have their focal depth at $33 \mathrm{~km}$. We conclude that Sanaga Shear Zone faults have average depth of $33 \mathrm{~km}$. This observation is consistent with our results which found crust thickness at about $35 \mathrm{~km}$ along the SSZ (Figure 2(b)).

\subsection{Seismic Source Region in Cameroon}

Source region model is built by delineating area where a given seismo-tectonic structure is active. It is done based on detailed geological studies of the area together with consistent and comprehensive historical and instrumental data of seismic events to substantiate the findings [22].

Several types of source modelling have been identified. Each source region model is adopted and assumed to have homogeneous seismicity, because seismic activities are scattered over a large area without a well identifiable point or specific fault location to warrant a point or a plane seismic source [23] [24]. Here, tectonic characteristics of each area and density of spatial distribution of seismic events are used to delineate Cameroon into four main Seismic Source Regions (Figure 5).

Seismic Source Region I: It corresponds to the area of "Mount Cameroon" volcano, in South-West Cameroon. From data recorded by temporary seismic network, $93.4 \%$ of events are located in this Region. Mostly

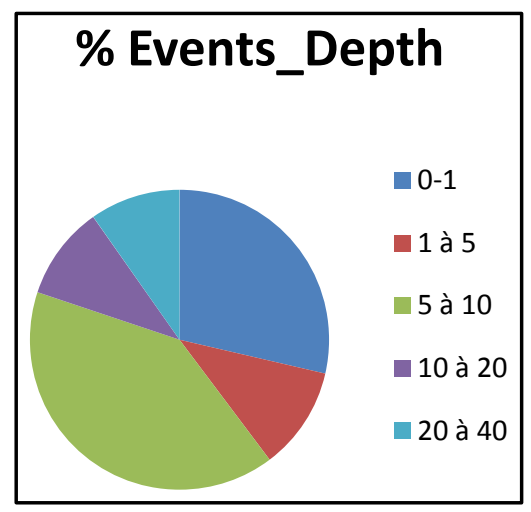

Figure 4. Percentage of events according to focal depth. 


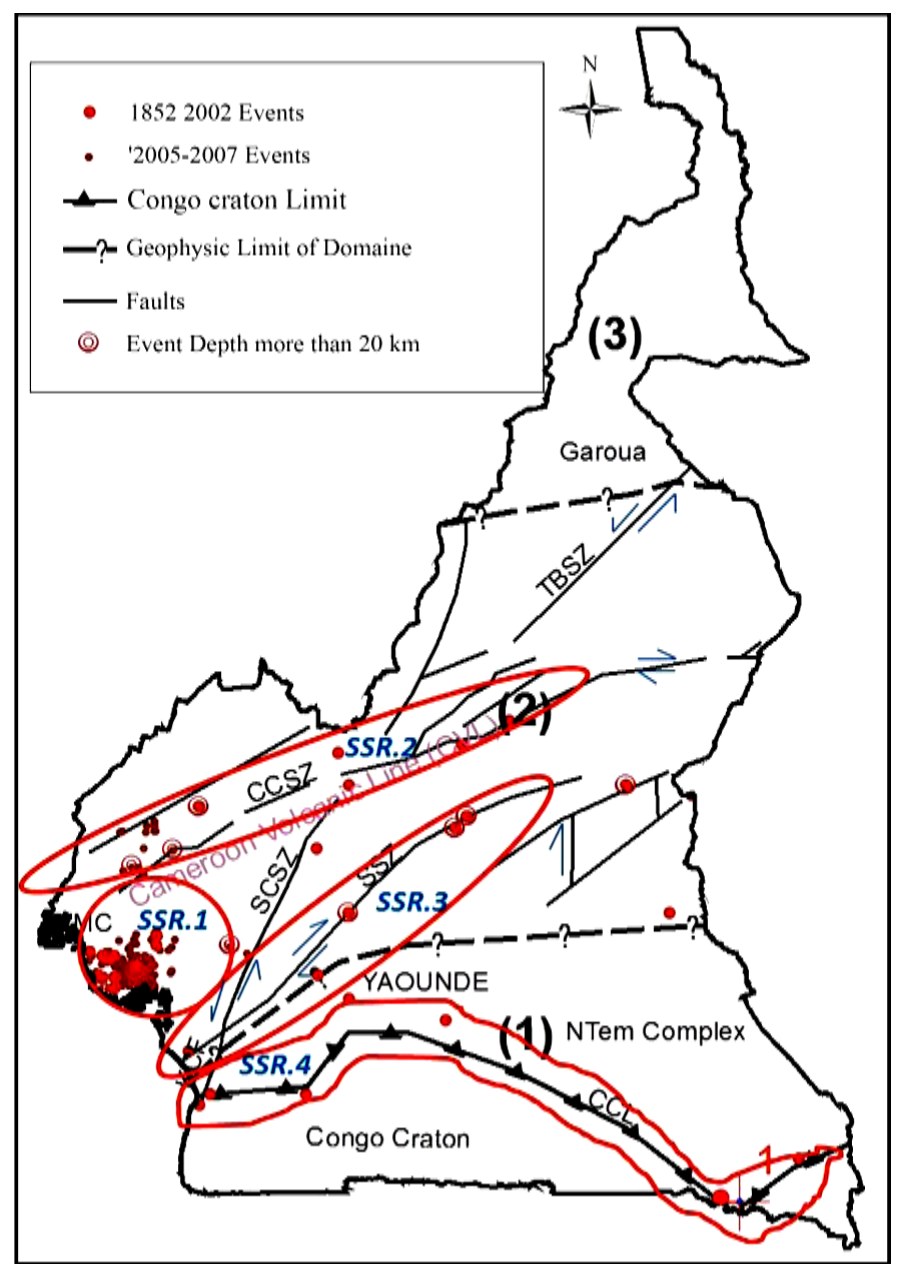

Figure 5. Seismic Source Regions (SSR); SSR. 1: Mount Cameroon Seismic Source; SSR. 2: Central Cameroon Seismic Source; SSR. 3: Sanaga Seismic Source; SSR. 4: Congo Craton Seismic Source.

events are shallow with depth inferior to $25 \mathrm{~km}$. However some historical (Table 1) and Instrumental (Table 2) events have their focal depth more than $25 \mathrm{~km}$ depth which correspond to the thickness of the crust in this region. Importantly, according to geotectonic data available, there are no faults identified in this area. We conclude that seismic activity in the "Mount Cameroon Source Region" is related to the magmatic activity, probably related to small-scale mantle convection mentioned by [18]. The maximum magnitude recorded in the source region is 4.4 $\mathrm{Mb}$; this suggests a weak seismicity.

Seismic Source Region II: It is also located in the South West region, in the North of mount Cameroon. In contrary to the "Seismic Source Region I", "Source Region II" is affected by southern segments faults of "Central Cameroon Shear Zone” (CCSZ). Shallow and very shallow events are found, but clusters have few events compared to Source Region I. The maximum magnitude recorded is $5.1 \mathrm{Mb}$; this might suggest a weak to moderate seismicity.

Seismic Source Region III: Central Cameroon, along Fault called "Sanaga Shear Zone" (SSZ). Despite the seeming diffuseness in seismicity, the epicenters of some events appear to be aligned along the Sanaga Shear Zone. Events occurring on the Sanaga Shear Zone (Seismic Source Region III) have their focal depth at $33 \mathrm{~km}$. We conclude that Sanaga Shear Zone faults have average depth of $33 \mathrm{~km}$. This observation is consistent with our results which found crust thickness at about $35 \mathrm{~km}$ along the SSZ (Figure 2). The maximum magnitude recorded in this source region was $5.8 \mathrm{Mb}$. Although this might suggest a moderate seismicity, the parameter of SSZ with average depth of $33 \mathrm{~km}$ and length of $900 \mathrm{~km}$, convinced us that it is an important seismogenic area.

Seismic Source Region IV follows the northern boundary of Congo Craton. One characteristic event has 
Table 1. Historical events with focal depth between 20 and 40 km. SSR: Seismic Source Region.

\begin{tabular}{ccccc}
\hline Latitude & Longitude & Depth & Magnitude & SSR \\
\hline 2 & 15 & 35 & 6 & IV \\
6 & 14 & 33 & 5.1 & III \\
3 & 8 & 33 & 5.4 & \\
5.8 & 10 & 33 & 5.1 & II \\
4.8 & 11.4 & 33 & 5.1 & III \\
5.6 & 12.4 & 33 & 5.8 & III \\
5.7 & 12.5 & 33 & 5.5 & III \\
\hline
\end{tabular}

Table 2. Instrumental events with focal depth between 20 and $40 \mathrm{~km}$.

\begin{tabular}{ccccc}
\hline Latitude & Longitude & Depth & Magnitude & SSR \\
\hline 4.5 & 10.29 & 39.83 & 4.3 & V \\
4.04 & 9.13 & 34.41 & 4.1 & I \\
4.33 & 9.51 & 33.15 & 4.8 & I \\
4.16 & 9.44 & 29.78 & 4.3 & I \\
4.1 & 9.07 & 29.31 & 4.9 & I \\
5.24 & 9.38 & 26.94 & 4.0 & I \\
4.26 & 9.41 & 26.93 & 4.2 & I \\
4.13 & 9.5 & 25.24 & 4.5 & II \\
\hline
\end{tabular}

focal depth at $33 \mathrm{~km}$ and magnitude of $6 \mathrm{M}$. Although most events are shallow and have weak magnitude, this characteristic event shows that segment faults of this source region can generate large earthquakes.

Spatial distribution of the epicenters shows an activity on the whole area of Central Domain (2). It is not easy to correlate activity of each event to a given seismo-tectonic structure. Some events are isolated and the others can't give coherent information about its location area.

\subsection{Impact on the Hazard Management in Cameroon}

The result of our study shows that, over the last few decades many parts of Cameroon have shown the potential to generate earthquakes with a magnitude of 6 or more. Although the recorded seismic activity is not very significant, the results of the present study cannot preclude the possibility of destructive seismic events occurring. In addition to its 20,000,000 inhabitants, many buildings with systemic and economic impacts are exposed.

The presence of buildings of all types from mud buildings to reinforced cement concrete framed structures and steel construction and evidence of improper and low quality construction practices makes Cameroon vulnerable even against average earthquakes. This study is a first step toward a comprehensive evaluation of the seismic hazard and risk analysis. The appropriate seismic safety assessments can be properly taken into account in Cameroon Code for Para-seismic Construction.

\section{Conclusions}

Cameroon is affected by many local and regional tectonic structures. This work, which integrates the most recent seismic data, was undertaken in an attempt to analyze and interpret crustal structure and seismic activity.

Crustal structure shows three main domains which are consistent with their contrasting tectonic environments. Very thin crust in S-W Cameroon results principally from area's location in a transition zone between continental crust to the East and oceanic crust of the Atlantic margin to the West. The Ntem complex which has the highest crust thickness is the equilibrium created by the uprising of Cameroon Volcanic Line. Besides, accord- 
ing to the crustal thickness map, both Ntem complex and CVL appear to be parallel (Figure 3).

It has been shown that the seismicity is heterogeneous. Shallow and weak magnitude earthquakes are predominant. Four Seismic Source regions are identified; three in the Central Domain and one in the South domain. The distribution of seismic activity is particularly denser in the area of Mount Cameroon and related to the magmatic activity. Elsewhere the seismicity, as induced by the tectonic activity, is weak to moderate. Sanaga Source Region is characterized by events with $33 \mathrm{~km}$ depth for $35 \mathrm{~km}$ of Crust thickness in this area; that allows one to think that the faults segments are deep for about $33 \mathrm{~km}$. An event with $33 \mathrm{~km}$ depth in Congo Craton Source Region allows also predicting deep faults.

For the whole study area of Cameroon, the seismicity is weak to moderate. It is related to the magmatic activity of Mount Cameroon on one hand, and on the other hand to the tectonic structures of CVL and the boundary of Congo Craton.

\section{References}

[1] Zhu, L. and Kanamori, H. (2000) Moho Depth Variation in Southern California from Teleseismic Receiver Functions. Journal of Geophysical Research, 105, 2969-2980. http://dx.doi.org/10.1029/1999JB900322

[2] Takam, T., Mokoto, A., Kokonyangi, J., Dunkley, D.J. and Nsifa, E.N. (2009) Paleo-Archaeancharnockite in the Ntem Complex, Congo Craton, Camroon: Insights from SHRIMP Zircon U-Pb Ages. Journal of Mineralogical and Petrological Sciences, 104, P1-P11. http://dx.doi.org/10.2465/jmps.080624

[3] Nedelec, A., Macaudière, J., Nzenti, J.P. and Barbey, P. (1986) Evolution structurale et métamorphique de la série de Mbalmayo (Cameroun): Implications pour la structure de la zone mobile panafricaine au contact du craton du Congo. Acad des Scies Paris, 303, 75-80.

[4] Dumont, J.F. (1986) Identification par télédétection de l'accident de la Sanaga (Cameroun). Sa position dans le contexte des grands accidents d'Afrique centrale et de la limite nord du craton congolais. Géodynamique, 1, 13-19.

[5] Mvondo, H., Owona, S., Mvondo-Ondoa, J. and Essono, J. (2007) Tectonic Evolution of the Yaoundé Segment of the Neoproterozoic Central African Orogenic Belt in Southern Cameroon. Canadian Journal of Earth Sciences, 44, 433444. http://dx.doi.org/10.1139/e06-107

[6] Ganwa, A.A., Frish, W., Siebel, W., Ekodeck, G.A., Shang, C.K. and Ngako, V. (2008) Archean Inheritances in the Pyroxene-Amphibole Bearing Gneiss of the Méiganga Area (Central North Cameroun): Geochemical and ${ }^{207} \mathrm{~Pb} /{ }^{206} \mathrm{~Pb}$ Age Imprints. Comptes Rendus Geoscience, 340, 211-222. http://dx.doi.org/10.1016/j.crte.2007.12.009

[7] Toteu, S.F., Van Schmus, W.R., Penaye, J. and Michard, A. (2001) New U-Pb and Sm-Nd Data from North-Central Cameroon and Its Bearing on the Pre-Pan-African History of Central Africa. Precambrian Research, 108, 45-73. http://dx.doi.org/10.1016/S0301-9268(00)00149-2

[8] Toteu, S. F., Penaye, J. and Poudjom, D.Y. (2004) Geodynamic Evolution of the Pan-African Belt in the Central Africa with Special Reference to Cameroon. Canadian Journal of Earth Sciences, 41, 73-85. http://dx.doi.org/10.1139/e03-079

[9] Dorbath, C., Dorbath, L., Fairhead, D. and Stuart, G.W. (1986) A Teleseismic Delay Time Study across the Central African Shear Zone in the Adamawa Region of Cameroon, West Africa. Geophysical Journal International, 86, 751766. http://dx.doi.org/10.1111/j.1365-246X.1986.tb00658.x

[10] Castaing, C., Feybesse, J.L., Thieblemont, D., Triboulet, C. and Chevremont, P. (1994) Palaeogeographical Recon structions of the Pan-African/Brasiliano Orogen: Closure of an Oceanic Domain or Intracontinental Convergence between Major Blocks? Precambrian Research, 67, 327-344. http://dx.doi.org/10.1016/0301-9268(94)90095-7

[11] Daly, M., Chorowicz, J. and Fairhead, J. (1989) Rift Basin Evolution in Africa: The Influence of Reactivated Steep Basement Shear Zones. In: Cooper, M.A. and Williams, G.D., Eds., Inversion Tectonics, Vol. 44, Geological Society, Special Publications, London, 309-334.

[12] Ndougsa-Mbarga, T., Yufenyiu, L.D., Yene-Atangana, J.Q. and Tabod, C. (2014) Analysis and 2.5D Delineation of the Northern Limit of the Congo Craton Based on Spectral Modeling of Aeromagnetic Data in Akonolinga-Mbama Area, Cameroon. Geofísica Internacional, 53, 5-16.

[13] Tokam, A.P.K., Tabod, T.C., Nyblade, A., Julià, J., Wiens, D.A. and Pasyanos, M.E. (2010) Structure of the Crust beneath Cameroon, West Africa, from the Joint Inversion of Rayleigh Wave Group Velocities and Receiver Functions. Geophysical Journal International, 183, 1061-1076. http://dx.doi.org/10.1111/j.1365-246X.2010.04776.X

[14] DePlaen, R.M., Bastow, I.D., Chambers, E.L., Keir, D., Gallacher, R.J. and Keane, J. (2014) The Development of Magmatism along the Cameroon Volcanic Line: Evidence from Seismicity and Seismic Anisotropy. Journal of Geophysical Research: Solid Earth, 119, 4233-4252. http://dx.doi.org/10.1002/2013JB010583 
[15] Reusch, A., Nyblade, A., Wiens, D., Shore, P., Ateba, B., Tabod, C. and Nnange, J. (2010) Upper Mantle Structure beneath Cameroon from Body Wave Tomography and the Origin of the CVL. Geochemistry, Geophysics, Geosystems, 11, Q10W07. http://dx.doi.org/10.1029/2010GC003200

[16] Pasyanos, M.E. and Nyblade, A.A. (2007) A Top to Bottom Lithospheric Study of Africa and Arabia. Tectonophysics, 444, 27-44. http://dx.doi.org/10.1016/j.tecto.2007.07.008

[17] Fishwick, S. (2010) Surface Wave Tomography: Imaging of the Lithosphere-Asthenosphere Boundary beneath Central and Southern Africa. Lithos, 120, 63-73. http://dx.doi.org/10.1016/j.lithos.2010.05.011

[18] Koch, F., Wiens, D., Nyblade, A., Shore, P., Tibi, R., Ateba, B., Tabod, C. and Nnange, J. (2012) Upper Mantle Anisotropy beneath the Cameroon Volcanic Line and Congo Craton from Shear Wave Splitting Measurements. Geophysical Journal International, 190, 75-86. http://dx.doi.org/10.1111/j.1365-246X.2012.05497.x

[19] Tadjou, J., Nouayou, R., Kamguia, J., Kande, H. and Manguelle-Dicoum, E. (2009) Gravity Analysis of the Boundary between the Congo Craton and the Pan-African Belt of Cameroon. Austrian Journal of Earth Sciences, 102, 71-79.

[20] Gallacher, R. and Bastow, I. (2012) The Development of Magmatism along the Cameroon Volcanic Line: Evidence from Teleseismic Receiver Functions. Tectonics, 31, TC3018. http://dx.doi.org/10.1029/2011TC003028

[21] IRGM: Institut National de Rechechrche Géologique et Minière (2002) Catalogue sismique du Cameroon. Yaoundé.

[22] Karnik, V. and Algermissen, S.T. (1977) Seimic Zoning UNESCO Report.

[23] Rizzo, P.C., Vaidya, N.R., Bazan, E. and Heberling, C.F. (1995) Seismic Hazard Assessment in the Southeastern United States. Earthquake Spectra, 11, 129-160. http://dx.doi.org/10.1193/1.1585806

[24] Abdalla, J.A., Mohamedzein, Y.E.A. and Wahab, A.A. (2001) Probabilistic Seismic Hazard Assessment of Sudan and Its Vicinity. Earthquake Spectra, 17, 399-415. http://dx.doi.org/10.1193/1.1586181 
Scientific Research Publishing (SCIRP) is one of the largest Open Access journal publishers. It is currently publishing more than 200 open access, online, peer-reviewed journals covering a wide range of academic disciplines. SCIRP serves the worldwide academic communities and contributes to the progress and application of science with its publication.

Other selected journals from SCIRP are listed as below. Submit your manuscript to us via either submit@scirp.org or Online Submission Portal.
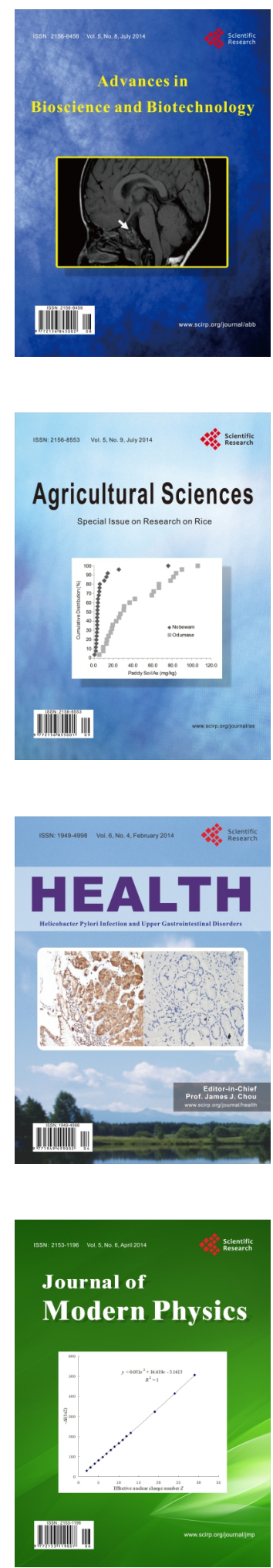
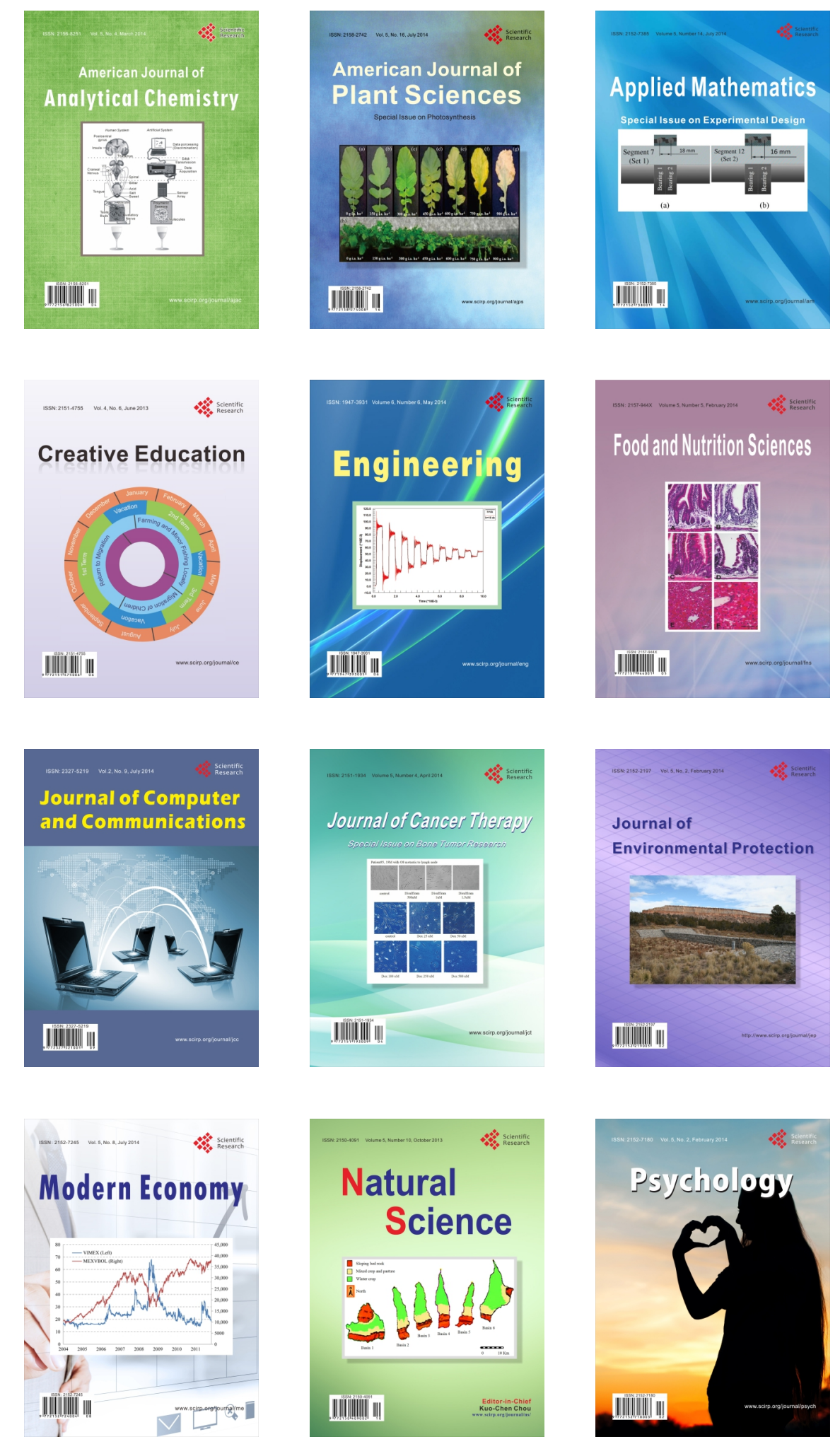